\title{
Oxygen deprivation and the cellular response to hypoxia in adipocytes - perspectives on white and brown adipose tissues in obesity
}

\author{
Paul Trayhurn ${ }^{1,2,3}$ * and Suliman Yousef Alomar ${ }^{2}$ \\ 1 Clore Laboratory, Buckingham Institute for Translational Medicine, University of Buckingham, Buckingham, UK \\ ${ }^{2}$ College of Science, King Saud University, Riyadh, Saudi Arabia \\ ${ }^{3}$ Obesity Biology Unit, Institute of Ageing and Chronic Diseases, University of Liverpool, Liverpool, UK
}

\section{Edited by:}

Daniela Patrizia Foti, Università

"Magna Graecia" di Catanzaro, Italy

Reviewed by:

Justin J. Rochford, University of Cambridge, UK

Jocelyne Magre, INSERM, France

${ }^{*}$ Correspondence:

Paul Trayhurn, Clore Laboratory,

Buckingham Institute for Translational

Medicine, University of Buckingham,

Hunter Street, Buckingham MK18

$1 E G, U K$

e-mail:p.trayhurn@liverpool.ac.uk
Relative hypoxia has been shown to develop in white adipose tissue depots of different types of obese mouse (genetic, dietary), and this leads to substantial changes in white adipocyte function. These changes include increased production of inflammation-related adipokines (such as IL-6, leptin, Angpt/4, and VEGF), an increase in glucose utilization and lactate production, and the induction of fibrosis and insulin resistance. Whether hypoxia also occurs in brown adipose tissue depots in obesity has been little considered. However, a recent study has reported low $\mathrm{pO}_{2}$ in brown fat of obese mice, this involving mitochondrial loss and dysfunction. We suggest that obesity-linked hypoxia may lead to similar alterations in brown adipocytes as in white fat cells - particularly changes in adipokine production, increased glucose uptake and lactate release, and insulin resistance. This would be expected to compromise thermogenic activity and the role of brown fat in glucose homeostasis and triglyceride clearance, underpinning the development of the metabolic syndrome. Hypoxia-induced augmentation of lactate production may also stimulate the "browning" of white fat depots through recruitment of UCP1 and the development of brite adipocytes.

Keywords: adipocyte, brite cell, brown adipose tissue, hypoxia, lactate, uncoupling protein-1, oxygen, white adipose tissue

\section{INTRODUCTION}

Oxygen is rarely considered as an essential nutrient in mammals and this is primarily because it is delivered through the lungs rather than in the diet via the gastrointestinal tract. However, at a cellular level, it is a key nutritional factor without which oxidative metabolism - particularly oxidative phosphorylation in mitochondria - cannot take place. The delivery of $\mathrm{O}_{2}$ to cells from the circulation is via a specific carrier protein, hemoglobin, paralleling the general mechanism by which a number of nutrients are delivered. At a whole-body level, the consequences of, and adaptations to, low $\mathrm{O}_{2}$ tension have been extensively investigated. This is especially so in relation to high altitude and in response to the $\mathrm{O}_{2}$ deprivation experienced during deep-sea diving. The effect of a lack of $\mathrm{O}_{2}$ has also been widely considered in relation to disorders such as obstructive pulmonary disease where lung function is impaired, and during the periodic reduction in $\mathrm{O}_{2}$ delivery in sleep apnea (1).

These states impact on the provision of $\mathrm{O}_{2}$ to the body as a whole. Changes in $\mathrm{O}_{2}$ level in individual tissues, specifically a reduction, can occur even when the total supply is not compromised. Examples include at the site of wounds during healing from tissue damage, and in the center of solid tumors (2-4). There is growing recognition that low $\mathrm{O}_{2}$ tension, indeed overt hypoxia, can occur in tissues with important implications for cellular function. White adipose tissue (WAT) is one site where hypoxia has been demonstrated and this occurs with the expansion of adipocyte size and total adipose mass in obesity (5-8).

In this article, we provide a perspective on the effects of hypoxia on the function of white adipocytes and consider, in particular, whether hypoxia also occurs in brown adipose tissue (BAT). It has been argued, of course, that collectively white and brown fat constitute a single adipose organ (9). We speculate on the effects that reduced $\mathrm{O}_{2}$ tension might have on the function of brown adipocytes and the possible implications for obesity and the metabolic syndrome.

\section{WHITE ADIPOSE TISSUE}

White adipose tissue, which is a major component of total body composition comprising at least $40 \%$ of body weight in obese adults, is the principal site of fuel storage and has major additional functions including in particular that of being a key endocrine organ. White adipocytes, the signature cell of WAT, are major secretory cells, releasing a multiplicity of lipid and protein moieties additional to the fatty acids mobilized by lipolysis $(8,10)$. Several pleiotropic protein hormones are synthesized and secreted by white adipocytes, the most prominent being leptin and adiponectin $(11,12)$. These hormones were first discovered in adipose tissue, and the identification of leptin firmly established white adipocytes as endocrine cells. 
Subsequent investigations demonstrated that white fat cells secrete a large and diverse range of "adipokines" (13-16), with proteomic studies suggesting that there are several hundred such protein factors (17). Multiple adipokines are associated with inflammation, including classical cytokines and chemokines such as TNF $\alpha$, IL-1 $\beta$, IL-6, and MCP-1 (13-15). The synthesis and release of a number of inflammation-related adipokines increase in obesity, adipose tissue depots becoming "inflamed" with the inflammatory state underpinning the development of obesity-associated diseases - particularly insulin resistance and the metabolic syndrome $(10,15,18,19)$.

Adipokines are not the only inflammation-related moieties produced by white adipocytes, various prostaglandins also being released (8). These lipid factors have received much less attention in considering the inflammatory response in adipose tissue. Indeed, there has been markedly less focus overall on the lipid secretions from the tissue - apart from fatty acids. This is despite white adipocytes releasing multiple lipid moieties, which include endocannabinoids (such as anandamide), cortisol (by the conversion of cortisone), vitamin $\mathrm{D}_{3}$, vitamin $\mathrm{A}$, and cholesterol - some of which are sequestered within WAT rather than being synthesized de novo $(1,8)$.

\section{HYPOXIA IN WHITE ADIPOSE TISSUE}

Hypoxia is one of the central mechanisms postulated to explain the development of inflammation and the subsequent metabolic dysfunction of WAT in obesity $(10,20,21)$. This is linked to the growing recognition that $\mathrm{O}_{2}$ levels are far from the same in all tissues, and neither are they constant. For example, while the general level of tissue oxygenation $\left(\mathrm{pO}_{2}\right)$ is $45-50 \mathrm{mmHg}$, that of the thymus is $10 \mathrm{mmHg}$, while for the brain it is as low as $0.4-8 \mathrm{mmHg}(3$, 22 ) - and the center of solid tumors can be essentially anoxic $(2,3)$. In the case of WAT, it was proposed that as fat mass expands in the obese, large adipocytes become distant from the vasculature and areas of $\mathrm{O}_{2}$ deprivation occur $(10,20)$. Hypoxia was subsequently demonstrated in WAT in various obese rodents - genetically obese $o b / o b$ and KKAy mice, and mice with diet-induced obesity (57). Two distinct experimental approaches documented hypoxia in these obese mice; in one, which utilized the hypoxia marker pimonidazole, low $\mathrm{pO}_{2}$ was shown qualitatively. Quantitative measurements have been obtained using needle-type $\mathrm{O}_{2}$ sensors, and these found between 2- and 3.5-fold reductions in $\mathrm{pO}_{2}$ in WAT of $o b / o b$ and dietary obese mice relative to lean controls - down to $15 \mathrm{mmHg}$ compared with $45-50 \mathrm{mmHg}$, for obese and lean animals, respectively $(5-7,23)$.

In contrast to the clear evidence for hypoxia in WAT in rodent obesity, the situation in obese humans is more problematic. Several earlier studies demonstrated reduced $\mathrm{pO}_{2}$ in human obesity, consistent with the more limited vascularization in the obese limited since the blood supply to WAT does not rise despite the substantial increase in the size of the fat depots (24-26). Proportionally, the vascular supply is reduced per unit adipose mass in obese humans, capillary density being lower than in the lean. A further key observation is that obese humans do not exhibit the post-prandial rise in blood flow to WAT that occurs in lean individuals $(27,28)$. While the degree of hypoxia is the modest in the human studies recording reduced $\mathrm{O}_{2}$ tension, two recent reports have found no evidence for lower $\mathrm{O}_{2}$ levels $(28,29)$. Indeed, in one study, hyperoxia rather than hypoxia was noted (28). In the study reporting neither hypoxia nor hyperoxia, reduced delivery of blood and lowered consumption of $\mathrm{O}_{2}$ were observed, nevertheless; in addition, there was a net release of lactate, consistent with anaerobic glycolysis (29). At present, it is not evident why such divergent results have been obtained, although methodological issues may be important.

In parallel with in vivo investigations on the $\mathrm{O}_{2}$ tension of WAT in obesity, extensive in vitro studies on the molecular and cellular response to hypoxia of adipocytes (human and rodent) in culture have been undertaken $(5,6,8,30-32)$. These initially focused on the expression (and in some cases release) of key adipokines, both those directly linked to inflammation and the signature adipocyte hormones leptin and adiponectin. The expression and release of leptin, VEGF, serum amyloid A, Angptl4, and IL-6, for example, are increased in the presence of hypoxia, while adiponectin production is reduced $(5,6,8,30-32)$. This is indicative of the induction of an inflammatory state. Microarray studies have shown that the expression of up to 1,300 genes is hypoxia-sensitive ( $~ 50 \%$ upregulated/ $~ 50 \%$ downregulated) in human adipocytes, indicating an extensive effect of low $\mathrm{O}_{2}$ tension on gene expression in these cells $(33,34)$. The genes encoding proteins in key pathways and processes modulated by low $\mathrm{pO}_{2}$ include those associated with glycolysis, mitochondrial (oxidative) metabolism, cell death, and inflammation $(33,34)$. Some of these changes clearly reflect a switch from aerobic to anaerobic metabolism.

Alterations in gene expression in hypoxia, not all of which are necessarily primary, are, of course, significant, but it is changes in metabolic function that are of greatest importance. Studies with 2deoxy-D-glucose demonstrate that glucose uptake into adipocytes is stimulated by hypoxia, and this is a transport-mediated process $(35,36)$. The key transporter involved is GLUT1, responsible for basal glucose uptake in many cells, since hypoxia induces a substantial increase in its expression and amount $(35,37)$. There is a parallel elevation in the release of lactate from hypoxic adipocytes, this also involving the recruitment of a specific transport protein - MCT1, a monocarboxylate transporter (38). Increases in glucose uptake and lactate release are indicative of the stimulation of anaerobic glycolysis and the levels of glycolytic enzymes, as well as the expression of genes linked to glycolysis, are raised in hypoxic adipocytes $(33,34,39)$.

Other functional changes in fat cells in response to low $\mathrm{pO}_{2}$ include the rates of lipolysis and lipogenesis. Lipolysis is reported as both increased and unchanged; however, the evidence for the former appears stronger $(23,30,40)$. Lipogenesis is reduced in hypoxia, as is the uptake of fatty acids, and the effect of reduced $\mathrm{pO}_{2}$ on these processes may be mediated through an inhibition of hexosamine biosynthesis $(23,40)$. A major direct effect of hypoxia on adipocyte function is the induction of insulin resistance. Thus, there is a loss of insulin-stimulated glucose uptake, as indicated by 2-deoxy-D-glucose studies, and an inhibition of the insulin signaling pathway - including a lack of phosphorylation of insulin receptor- $\beta$ and insulin receptor substrate $(23,36)$. Insulin resistance may well be the key element in adipose tissue dysfunction induced by hypoxia in obesity. 
A further area of adipocyte function in which low $\mathrm{O}_{2}$ tension plays a role is in the induction of a pro-fibrotic transcriptional program, fibrosis resulting from the disruption of the extracellular matrix $(41,42)$. Fibrosis is now considered as part of adipose tissue dysfunction in obesity, and the expression of a number of genes encoding proteins of the extracellular matrix, including specific collagens, is altered in adipocytes by hypoxia (42).

Other cells in WAT additional to adipocytes are sensitive to hypoxia, including macrophages and pre-adipocytes. In the case of macrophages, the inflammatory state is stimulated by low $\mathrm{pO}_{2}(6$, $43,44)$. A major effect of hypoxia on pre-adipocytes is to inhibit the differentiation of these precursor cells into adipocytes, this involving a downregulation of PPAR $\gamma$ through the key hypoxiainducible transcription factor, HIF-1 (8). A particularly intriguing effect of low $\mathrm{pO}_{2}$ on pre-adipocytes is their conversion into leptin-secreting, endocrine cells; prior to their differentiation into mature adipocytes, pre-adipocytes do not express the Lep gene (45). This effect is evident with overt hypoxia $\left(1 \% \mathrm{O}_{2}\right)$ and an important question is at what $\mathrm{O}_{2}$ level pre-adipocytes express the Lep gene and secrete functional leptin. It has been argued that the lack of leptin production by pre-adipocytes cultured under normal conditions may be an artifact, reflecting an inhibitory effect of hyperoxia since the cells are customarily incubated under $21 \% \mathrm{O}_{2}(1)$.

This raises the broader question of the appropriate $\mathrm{O}_{2}$ tension at which to culture or incubate cells in general. Again, the $21 \% \mathrm{O}_{2}$ present in air is usually employed, but this represents a considerably higher $\mathrm{O}_{2}$ tension than the $45-50 \mathrm{mmHg}(\sim 7 \%$ $\mathrm{O}_{2}$ equivalent) that most tissues normally experience. A study on human adipocytes exposed to different levels of $\mathrm{O}_{2}$ indicates that at physiological levels of oxygenation the cells exhibit increased expression of those adipokine genes that are hypoxia-sensitive and there is elevated secretion of the functional protein relative to $21 \%$ $\mathrm{O}_{2}$ (37). Similarly, glucose uptake and lactate release, together with the expression of their respective transporters, are greater at $7 \% \mathrm{O}_{2}$ than at so-called "normoxia" (37). Thus, at physiological levels of $\mathrm{O}_{2}$ adipocytes (and other cells) are relatively hypoxic and exhibit some of the cellular changes characteristic of this state - though greater effects are evident with $1 \% \mathrm{O}_{2}$.

\section{BROWN ADIPOSE TISSUE}

There has been little consideration of whether hypoxia occurs in BAT in obesity, and if so whether the key functions of brown adipocytes are modified. The primary role of BAT as a specialized organ for generating heat by non-shivering mechanisms (46, 47 ) is dependent on the extensive vascularization that is evident in the tissue. A substantial blood supply is required to provide $\mathrm{O}_{2}$ and other nutrients to fuel thermogenesis and to rapidly distribute heat throughout the body - in part, to ensure that BAT is not itself damaged through an inappropriate elevation in local temperature. Heat constitutes, of course, the primary form of cross-talk from BAT to other tissues.

Heat is generated in brown adipocytes through the uncoupling of oxidative phosphorylation such that the proton gradient across the inner mitochondrial membrane is dissipated as heat rather than being coupled to ATP synthesis $(47,48)$. This proton conductance pathway is dependent on, and regulated by, the
32,000 mol. wt. mitochondrial uncoupling protein, UCP1 $(49,50)$. Thermogenesis is stimulated by noradrenaline released from the sympathetic nervous system, with the sympathetic system also playing a central role in the development of thermogenic capacity (51). By virtue of its role in heat production for thermoregulation, BAT is prominent in small rodents adapted to the cold, in the newborn of precocial species (such as lambs and cattle), and in hibernators (such as ground squirrels). BAT is also a site of dietinduced thermogenesis with this form of adaptive heat production being a component in the regulation of energy balance and body fat (52-54). Throughout the 1980s, BAT was a key focus of obesity research, reflecting the proposition that reduced thermogenesis is important in the etiology of the obese state (54-56).

The recent renewed interest in BAT has followed from reports in which definitive evidence for metabolically active brown fat in adult humans has been presented. The application of fluorodeoxyglucose positron emission tomography (FDG-PET) has identified sites of fat tissue that exhibit high glucose uptake (57), and together with immunostaining for UCP1 has unambiguously identified BAT in adult humans (58-60). Subsequent reports have demonstrated that the abundance and thermogenic activity of brown fat in humans exhibits considerable plasticity, FDG-PET investigations indicating that acute exposure to cold activates BAT in humans (59, 61-63). Importantly, in relation to energy balance, observations from FDG-PET indicate an inverse relationship of BAT activity to age and BMI, the tissue being less active, or less evident, in older subjects and in the obese (64-66).

While the central role of BAT is to generate heat, brown adipocytes produce and secrete specific protein signals - in effect adipokines similar to white fat - and these include leptin and IL-6 (67-69). The actions of these adipokines is likely to be essentially autocrine/paracrine, rather than endocrine, since the contribution from brown fat to circulating levels will be small relative to that of WAT. Whether the "adipokinome" in brown adipocytes is extensive is unknown. BAT is increasingly recognized to have direct metabolic functions, FDG-PET studies showing that the tissue has a high rate of glucose uptake, which can be stimulated by insulin as well as cold exposure (59,61-63). Recent reports have demonstrated that brown fat is important in glucose homeostasis with the tissue being proposed as a major organ in glucose disposal and insulin sensitivity $(70,71)$. A further metabolic role now attributed to the tissue is in triglyceride clearance, particularly during cold exposure $(70,72)$.

An apparent substantive contribution of BAT to glucose homeostasis, insulin sensitivity and lipid clearance has led to the suggestion that reduced activity of the tissue may be implicated in the development of the metabolic syndrome, with re-activation potentially leading to a reversal of the syndrome $(72,73)$.

\section{HYPOXIA IN BROWN ADIPOSE TISSUE}

As noted above, BAT is highly vascularized consistent with the need to supply $\mathrm{O}_{2}$ and other nutrients to meet the metabolic demands of thermogenesis. Studies on regional blood flow in the late $1970 \mathrm{~s}$ indicated that the tissue is responsible for $>50 \%$ of total nonshivering thermogenesis in rats acclimated to the cold, with up to one-third of the total cardiac output being directed toward BAT during maximal thermogenesis $(74,75)$. In the case of Sultzer's 
vein, which drains the main interscapular depot in rodents, $\mathrm{O}_{2}$ extraction appears almost total (76).

Increased lipid deposition occurs in brown adipocytes in obesity with BAT enlarging in obese animals, similar to the expansion of white fat depots. The increase in adipocyte size in BAT raises the possibility that pockets of reduced $\mathrm{O}_{2}$ tension develop in the tissue in the obese and that this leads to the inhibition of the acute thermogenic response. Indeed, hypoxia may have major effects on gene expression and cellular metabolism in brown adipocytes, as in white, BAT function being compromised through the development of insulin resistance and reduced thermogenesis. BAT thermogenesis is recognized to be reduced in obese rodents, as indicated by measurements of regional blood flow and $\mathrm{O}_{2}$ utilization in response to noradrenaline, as well as from studies on the amount and activity of UCP1 $(55,56,77)$.

Hypoxia has been observed through pimonidazole staining in BAT of lean mice exposed to the cold $\left(4^{\circ} \mathrm{C}\right)$, but it is not evident in mice acclimated to the warm $\left(30^{\circ} \mathrm{C}\right) ; U_{c p} 1$ knockout indicates that it occurs only with thermogenic activity (78). A recent study has directly examined whether there is hypoxia in brown fat in the obese and described evidence for vascular "rarefaction" in BAT of mice with diet-induced obesity, leading to a "whitening" of the tissue with enlarged lipid droplets together with mitochondrial dysfunction and loss (79). Hypoxia was demonstrated in the obese by pimonidazole staining and with a fiber-optic $\mathrm{O}_{2}$ sensor, the latter indicating a $>5$-fold reduction in $\mathrm{pO}_{2}$ compared with BAT of lean mice - a greater degree of hypoxia than occurred in WAT of the same animals. Among the other changes observed in the obese BAT were increases in the level of the hypoxia-sensitive transcription factor subunit, HIF-1 $\alpha$, and falls in Ucp1 expression and $\beta$-adrenergic signaling (79).

By analogy with white adipocytes, there are a number of other potential effects of hypoxia on brown adipocytes in obesity (Figure 1). These include changes in the transcription of a range of hypoxia-sensitive genes, including those encoding adipokines; the expression of leptin, VEGF, and IL-6, for example, may increase. Glucose uptake would be expected to rise through increased expression and recruitment of GLUT1. Insulin-stimulated glucose uptake, on the other hand, may fall through the development of insulin resistance. A loss of insulin sensitivity is evident in BAT of obese animals and occurs in $o b / o b$ mice soon after weaning (80, 81). This development of resistance is associated with a reduction in acute thermogenesis, and its reversal with ciglitazone restores the thermogenic response of BAT to cold (82).

Further potential metabolic changes in brown adipocytes in response to low $\mathrm{O}_{2}$ tension include the induction of fibrosis and a fall in lipogenesis and fatty acid uptake. Reduced lipid uptake as well as the induction of insulin resistance would be consistent with hypoxia being a mechanism for the development of the metabolic syndrome in obesity, given the postulated role of BAT in glucose homeostasis and triglyceride clearance. This, together with direct effects on limiting thermogenesis itself, suggests that hypoxia has the potential to severely compromise BAT function with important implication for metabolic homeostasis and disease processes.

If mitochondrial loss and dysfunction are induced in BAT by hypoxia and glucose utilization is elevated, this would indicate a switch to anaerobic glycolysis. One of the consequences of such a switch would be an increase in lactate production and release,

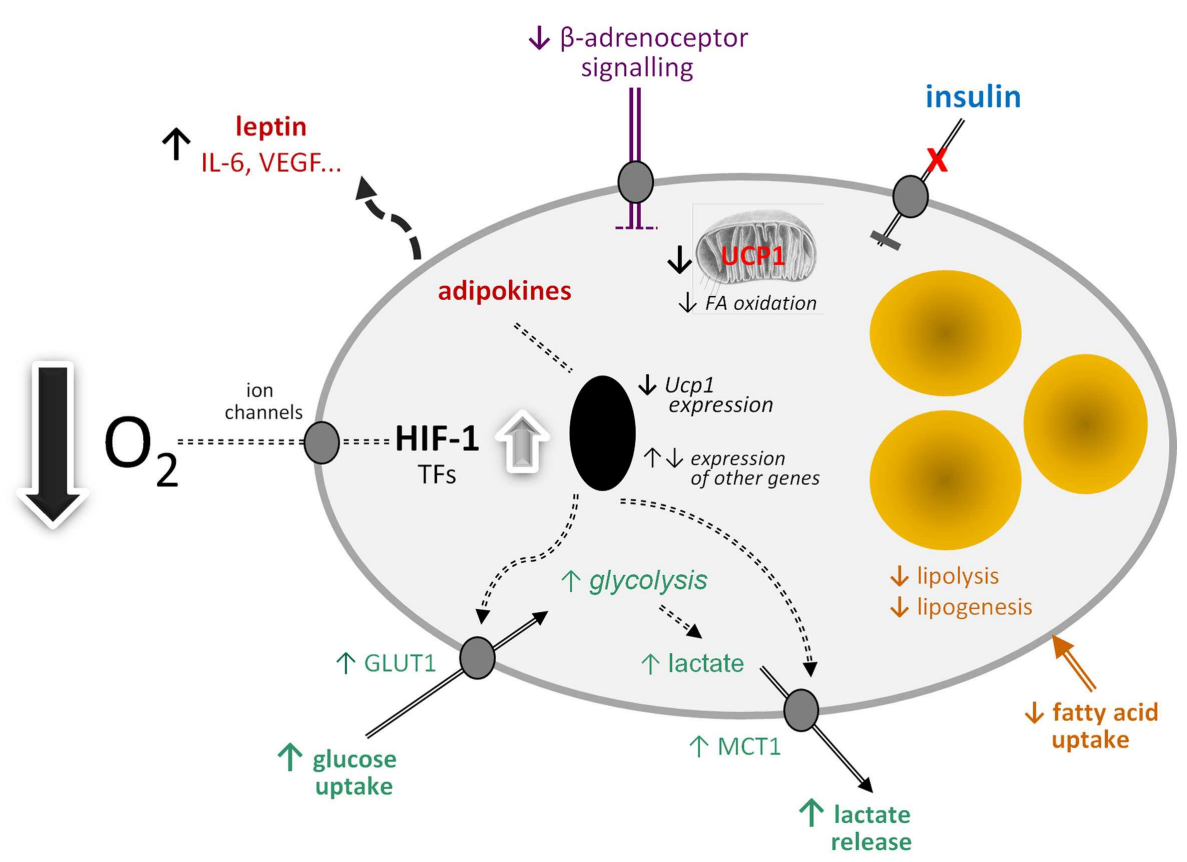

FIGURE 1 | Schematic view of the potential effects of hypoxia on brown adipocyte function. FA, fatty acid; GLUT1, facilitative glucose transporter-1; HIF-1, hypoxia-inducible factor-1; IL-6, interleukin-6; MCT1, monocarboxylate transporter-1; TFs, transcription factors; Ucp1, uncoupling protein-1 (gene); VEGF, vascular endothelial growth factor. 
involving the further recruitment of the MCT1 transporter. Lactate has recently emerged as an important metabolic signal, the functions attributed to it including the stimulation of inflammation in macrophages and - importantly - mediation of the anti-lipolytic effect of insulin $(83,84)$. This anti-lipolytic action is via the GPR81 receptor, which is expressed principally in adipose tissues (84).

\section{HYPOXIA AND THE RECRUITMENT OF BRITE ADIPOCYTES}

A further major function recently identified for lactate is in the "browning" of white adipocytes (85). The concept of browning has emerged with the recognition that there is a third type of adipocyte in addition to white and brown fat cells - the brite (or beige) adipocyte. Brite cells are found especially in white fat depots and have many, though not all, of the molecular characteristics of brown adipocytes $(86,87)$. The key feature shared by brite and brown adipocytes is the presence of UCP1, providing the potential for thermogenesis $(86,88)$.

Cold exposure of mice results in an elevation in circulating lactate levels and Mct1 gene expression is stimulated in both BAT and WAT (85). Treatment with lactate, in vivo or in vitro, induces Ucp1 gene expression in white adipocytes and the expression of genes associated with fatty acid oxidation and mitochondrial function, indicative of the recruitment of a thermogenic profile (85). Lactate does not lead to the induction of UCP1 in white fat cells through the GPR81 receptor, but rather by modulation of MCT activity; preventing lactate influx by pharmacological inhibition of MCTs suppressed the lactate-induced expression of Ucp1. Correspondingly, knockdown of MCT4, the transporter responsible for lactate efflux, strongly enhanced $U c p 1$ expression in adipocytes. It is suggested that the lactate-induced expression of Ucp 1 in white adipocytes, which is independent of HIF-1 $\alpha$, is a mechanism for reducing oxidative stress resulting from high intracellular lactate levels (85).
There are, of course, an increasing number of agents which have been reported to stimulate "browning" (89), but lactate is of particular interest because of its direct physiological relevance. WAT is an important site of lactate production and the levels in the tissue are increased in obesity $(5,90)$. A model can be proposed in which lactate production rises in WAT in obesity in response to developing hypoxia as large adipocytes switch from aerobic to anaerobic metabolism (Figure 2). The lactate then stimulates $U c p 1$ expression in neighboring white adipocytes, through an autocrine/paracrine action, leading to the recruitment of brite cells and the emergence of the "browning" phenotype in WAT. This could reflect a counter-regulatory response with the accumulation of large adipocytes resulting, via a hypoxia-induced elevation in lactate, in the production of thermogenic cells, which would oxidize lipid. However, the extent to which brite adipocytes may contribute to thermogenesis is debatable, with an extensive vascularization being one of the factors required for clusters of brite cells to make a significant contribution to adaptive heat production.

\section{CODA}

The effects of hypoxia on white adipocytes are extensive, ranging from the stimulation of the production of adipokines linked to inflammation to the induction of insulin resistance. Hypoxia also occurs in BAT in obesity, compromising thermogenic activity and potentially the role of the tissue in metabolic homeostasis. Mitochondrial loss and dysfunction, insulin resistance, fibrosis, increased glucose uptake, and lactate production may all occur in BAT following hypoxia, paralleling many of the changes in WAT induced by low $\mathrm{pO}_{2}$. Hypoxia-induced increases in lactate production by white adipocytes in obese WAT provides a signal for the induction of browning such that Ucp1 is expressed and brite fat cells recruited.

It is suggested that reduced $\mathrm{O}_{2}$ tension may be a critical influence on all forms of adipose tissue in obesity, profoundly

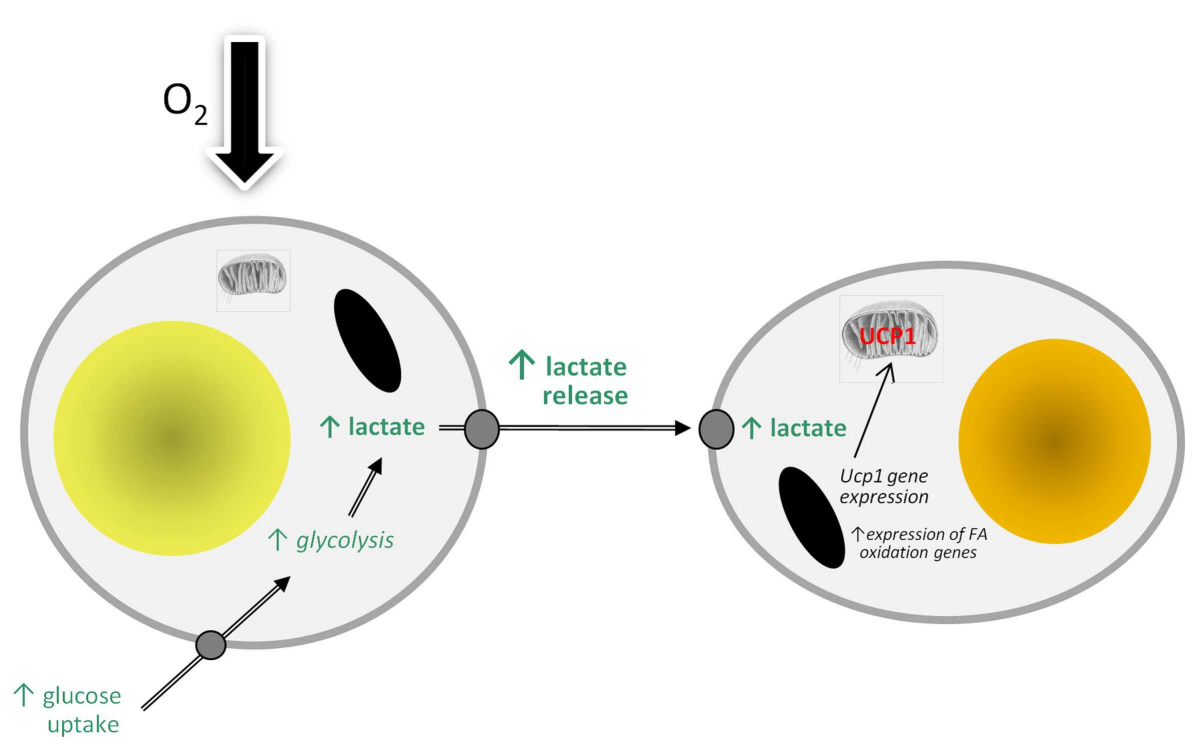

FIGURE 2 | Model of how hypoxia may lead to the recruitment of brite adipocytes and the "browning" of white adipose tissue depots through stimulating the production and release of lactate. FA, fatty acid; UCP1, uncoupling protein-1. 
altering the function of classical white and brown adipocytes and stimulating the development of brite fat cells.

\section{ACKNOWLEDGMENTS}

The authors are grateful to the Distinguished Scientist Program at King Saud University for financial support.

\section{REFERENCES}

1. Trayhurn P. Hypoxia and adipocyte physiology: implications for adipose tissue dysfunction in obesity. Annu Rev Nutr (2014) 34:207-36. doi:10.1146/annurevnutr-071812-161156

2. Semenza GL. Targeting HIF-1 for cancer therapy. Nat Rev Cancer (2003) 3:721-32. doi:10.1038/nrc1187

3. Brahimi-Horn MC, Pouysségur J. Oxygen, a source of life and stress. FEBS Lett (2007) 581:3582-91. doi:10.1016/j.febslet.2007.06.018

4. Brahimi-Horn C, Pouysségur J. Hypoxia in cancer cell metabolism and $\mathrm{pH}$ regulation. Essays Biochem (2007) 43:165-78. doi:10.1042/BSE0430165

5. Hosogai N, Fukuhara A, Oshima K, Miyata Y, Tanaka S, Segawa K, et al. Adipose tissue hypoxia in obesity and its impact on adipocytokine dysregulation. Diabetes (2007) 56:901-11. doi:10.2337/db06-0911

6. Ye J, Gao Z, Yin J, He Q. Hypoxia is a potential risk factor for chronic inflammation and adiponectin reduction in adipose tissue of $o b / o b$ and dietary obese mice. Am J Physiol Endocrinol Metab (2007) 293:E1118-28. doi:10.1152/ajpendo. 00435.2007

7. Rausch ME, Weisberg SP, Vardhana P, Tortorielllo DV. Obesity in C57BL/6J mice is characterised by adipose tissue hypoxia and cytotoxic T-cell infiltration. Int J Obes (Lond) (2008) 32:451-63. doi:10.1038/sj.ijo.0803744

8. Trayhurn P. Hypoxia and adipose tissue function and dysfunction in obesity. Physiol Rev (2013) 93:1-21. doi:10.1152/physrev.00017.2012

9. Cinti S. The adipose organ. Prostaglandins Leukot Essent Fatty Acids (2005) 73:9-15. doi:10.1016/j.plefa.2005.04.010

10. Trayhurn P, Wood IS. Adipokines: Inflammation and the pleiotropic role of white adipose tissue. Br J Nutr (2004) 92:347-55. doi:10.1079/BJN20041213

11. Zhang YY, Proenca R, Maffei M, Barone M, Leopold L, Friedman JM. Positional cloning of the mouse obese gene and its human homolog. Nature (1994) 372:425-32. doi:10.1038/372425a0

12. Maeda K, Okubo K, Shimomura I, Mizuno K, Matsuzawa Y, Matsubara K. Analysis of an expression profile of genes in the human adipose tissue. Gene (1997) 190:227-35. doi:10.1016/S0378-1119(96)00730-5

13. Frühbeck G, Gómez-Ambrosi J, Muruzabal FJ, Burrell MA. The adipocyte: a model for integration of endocrine and metabolic signaling in energy metabolism regulation. Am J Physiol Endocrinol Metab (2001) 280:E827-47.

14. Trayhurn P, Beattie JH. Physiological role of adipose tissue: white adipose tissue as an endocrine and secretory organ. Proc Nutr Soc (2001) 60:329-39. doi:10.1079/PNS200194

15. Rajala MW, Scherer PE. The adipocyte - at the crossroads of energy homeostasis, inflammation, and atherosclerosis. Endocrinology (2003) 144:3765-73. doi:10.1210/en.2003-0580

16. Rosen ED, Spiegelman BM. Adipocytes as regulators of energy balance and glucose homeostasis. Nature (2006) 444:847-53. doi:10.1038/nature05483

17. Dahlman I, Elsen M, Tennagels N, Korn M, Brockmann B, Sell H, et al. Functional annotation of the human fat cell secretome. Arch Physiol Biochem (2012) 118:84-91. doi:10.3109/13813455.2012.685745

18. Trayhurn P. Endocrine and signalling role of adipose tissue: new perspectives on fat. Acta Physiol Scand (2005) 184:285-93. doi:10.1111/j.1365-201X.2005. 01468.x

19. Hotamisligil GS. Inflammation and metabolic disorders. Nature (2006) 444:860-7. doi:10.1038/nature05485

20. Trayhurn P, Wang B, Wood IS. Hypoxia in adipose tissue: a basis for the dysregulation of tissue function in obesity? Br J Nutr (2008) 100:227-35. doi:10.1017/S0007114508971282

21. Ye J. Emerging role of adipose tissue hypoxia in obesity and insulin resistance. Int J Obes (Lond) (2008) 33:54-66. doi:10.1038/ijo.2008.229

22. Erecinska M, Silver IA. Tissue oxygen tension and brain sensitivity to hypoxia. Respir Physiol (2001) 128:263-76. doi:10.1016/S0034-5687(01)00306-1

23. Yin J, Gao Z, He Q, Zhou D, Guo Z, Ye J. Role of hypoxia in obesity-induced disorders of glucose and lipid metabolism in adipose tissue. Am J Physiol Endocrinol Metab (2009) 296:E333-42. doi:10.1152/ajpendo.90760.2008
24. Kabon B, Nagele A, Reddy D, Eagon C, Fleshman JW, Sessler DI, et al. Obesity decreases perioperative tissue oxygenation. Anesthesiology (2004) 100:274-80. doi:10.1097/00000542-200402000-00015

25. Pasarica M, Sereda OR, Redman LM, Albarado DC, Hymel DT, Roan LE, et al. Reduced adipose tissue oxygenation in human obesity: evidence for rarefaction, macrophage chemotaxis, and inflammation without an angiogenic response. Diabetes (2009) 58:718-25. doi:10.2337/db08-1098

26. Pasarica M, Rood J, Ravussin E, Schwarz J-M, Smith SR, Redman LM. Reduced oxygenation in human obese adipose tissue is associated with impaired insulin suppression of lipolysis. J Clin Endocrinol Metab (2010) 95:4052-5. doi:10.1210/ jc. 2009-2377

27. Karpe F, Fielding BA, Ilic V, Macdonald IA, Summers LKM, Frayn KN. Impaired postprandial adipose tissue blood flow response is related to aspects of insulin sensitivity. Diabetes (2002) 51:2467-73. doi:10.2337/diabetes.51.8.2467

28. Goossens GH, Bizzarri A, Venteclef N, Essers Y, Cleutjens JP, Konings E, et al. Increased adipose tissue oxygen tension in obese compared with lean men is accompanied by insulin resistance, impaired adipose tissue capillarization, and inflammation. Circulation (2011) 124:67-76. doi:10.1161/ CIRCULATIONAHA.111.027813

29. Hodson L, Humphreys SM, Karpe F, Frayn KN. Metabolic signatures of human adipose tissue hypoxia in obesity. Diabetes (2013) 62:1417-25. doi:10.2337/ db12-1032

30. Lolmède K, Durand de Saint Front V, Galitzky J, Lafontan M, Bouloumié A. Effects of hypoxia on the expression of proangiogenic factors in differentiated 3T3-F442A adipocytes. Int J Obes Relat Metab Disord (2003) 27:1187-95. doi:10.1038/sj.ijo.0802407

31. Wang B, Wood IS, Trayhurn P. Dysregulation of the expression and secretion of inflammation-related adipokines by hypoxia in human adipocytes. Pflügers Arch (2007) 455:479-92. doi:10.1007/s00424-007-0301-8

32. Chen B, Lam KSL, Wang Y, Wu D, Lam MC, Shen J, et al. Hypoxia dysregulates the production of adiponectin and plasminogen activator inhibitor-1 independent of reactive oxygen species in adipocytes. Biochem Biophys Res Commun (2006) 341:549-56. doi:10.1016/j.bbrc.2006.01.004

33. Geiger G, Leiherer A, Muendlein A, Stark N, Geller-Rhomberg S, Saely CH, et al. Identification of hypoxia-induced genes in human SGBS adipocytes by microarray analysis. PLoS One (2011) 6:e26465. doi:10.1371/journal.pone. 0026465

34. Mazzatti D, Lim F-L, O'Hara A, Wood IS, Trayhurn P. A microarray analysis of the hypoxia-induced modulation of gene expression in human adipocytes. Arch Physiol Biochem (2012) 118:112-20. doi:10.3109/13813455.2012.654611

35. Wood IS, Wang B, Lorente-Cebrian S, Trayhurn P. Hypoxia increases expression of selective facilitative glucose transporters (GLUT) and 2-deoxy-D-glucose uptake in human adipocytes. Biochem Biophys Res Commun (2007) 361:468-73. doi:10.1016/j.bbrc.2007.07.032

36. Regazzetti C, Peraldi P, Gremeaux T, Najem-Lendom R, Ben-Sahra I, Cormont $\mathrm{M}$, et al. Hypoxia decreases insulin signaling pathways in adipocytes. Diabetes (2009) 58:95-103. doi:10.2337/db08-0457

37. Wood I, Stezhka T, Trayhurn P. Modulation of adipokine production, glucose uptake and lactate release in human adipocytes by small changes in oxygen tension. Pflügers Arch (2011) 462:469-77. doi:10.1007/s00424-011-0985-7

38. Pérez de Heredia F, Wood IS, Trayhurn P. Hypoxia stimulates lactate release and modulates monocarboxylate transporter (MCT1, MCT2, and MCT4) expression in human adipocytes. Pflügers Arch (2010) 459:509-18. doi:10.1007/ s00424-009-0750-3

39. Choi S, Cho K, Kim J, Yea K, Park G, Lee J, et al. Comparative proteome analysis using amine-reactive isobaric tagging reagents coupled with 2D LC/MS/MS in 3T3-L1 adipocytes following hypoxia or normoxia. Biochem Biophys Res Commun (2009) 383:135-40. doi:10.1016/j.bbrc.2009.03.124

40. O'Rourke RW, Meyer KA, Gaston G, White AE, Lumeng CN, Marks DL. Hexosamine biosynthesis is a possible mechanism underlying hypoxia's effects on lipid metabolism in human adipocytes. PLoS One (2013) 8:e71165. doi:10.1371/ journal.pone.0071165

41. Halberg N, Khan T, Trujillo ME, Wernstedt-Asterholm I, Attie AD, Sherwani S, et al. Hypoxia-inducible factor $1 \alpha$ induces fibrosis and insulin resistance in white adipose tissue. Mol Cell Biol (2009) 29:4467-83. doi:10.1128/MCB.00192-09

42. Sun K, Tordjman J, Clement K, Scherer PE. Fibrosis and adipose tissue dysfunction. Cell Metab (2013) 18:470-7. doi:10.1016/j.cmet.2013.06.016

43. Lewis JS, Lee JA, Underwood JC, Harris AL, Lewis CE. Macrophage responses to hypoxia: relevance to disease mechanisms. J Leukoc Biol (1999) 66:889-900. 
44. Murdoch C, Muthana M, Lewis CE. Hypoxia regulates macrophage functions in inflammation. J Immunol (2005) 175:6257-63. doi:10.4049/jimmunol. 175.10.6257

45. Wang B, Wood IS, Trayhurn P. Hypoxia induces leptin gene expression and secretion in human preadipocytes: differential effects of hypoxia on adipokine expression by preadipocytes. J Endocrinol (2008) 198:127-34. doi:10.1677/JOE08-0156

46. Smith RE, Horwitz BA. Brown fat and thermogenesis. Physiol Rev (1969) 49:330-425

47. Cannon B, Nedergaard J. Brown adipose tissue: function and physiological significance. Physiol Rev (2004) 84:277-359. doi:10.1152/physrev.00015.2003

48. Nicholls DG, Locke RM. Thermogenic mechanisms in brown fat. Physiol Rev (1984) 64:1-64.

49. Ricquier D, Kader JC. Mitochondrial protein alterations in active brown fat: a sodium dodecyl sulfate-polyacrylamide gel electrophoretic study. Biochem Biophys Res Commun (1976) 73:577-83. doi:10.1016/0006-291X(76)90849-4

50. Ricquier D. Molecular biology of brown adipose tissue. Proc Nutr Soc (1989) 48:183-7. doi:10.1079/PNS19890028

51. Himms-Hagen J. Neural control of brown adipose tissue thermogenesis, hypertrophy, and atrophy. Front Neuroendocrinol (1991) 12:38-93.

52. Rothwell NJ, Stock MJ. A role for brown adipose tissue in diet-induced thermogenesis. Nature (1979) 281:31-5. doi:10.1038/281031a0

53. Brooks SL, Rothwell NJ, Stock MJ, Goodbody AE, Trayhurn P. Increased proton conductance pathway in brown adipose tissue mitochondria of rats exhibiting diet-induced thermogenesis. Nature (1980) 286:274-6. doi:10.1038/ 286274a0

54. Rothwell NJ, Stock MJ. Brown adipose tissue. Recent Adv Physiol (1986) 10:349-82.

55. Trayhurn P. Brown adipose tissue and energy balance. In: Trayhurn P, Nicholls DG, editors. Brown Adipose Tissue. London: Edward Arnold (1986). p. 299-388.

56. Himms-Hagen J. Brown adipose tissue thermogenesis and obesity. Prog Lipid Res (1989) 28:67-115. doi:10.1016/0163-7827(89)90009-X

57. Nedergaard J, Bengtsson T, Cannon B. Unexpected evidence for active brown adipose tissue in adult humans. Am J Physiol Endocrinol Metab (2007) 293:E444-52. doi:10.1152/ajpendo.00691.2006

58. Cypess AM, Lehman S, Williams G, Tal I, Rodman D, Goldfine AB, et al. Identification and importance of brown adipose tissue in adult humans. $N$ Engl J Med (2009) 360:1509-17. doi:10.1056/NEJMoa0810780

59. Virtanen KA, Lidell ME, Orava J, Heglind M, Westergren R, Niemi T, et al. Functional brown adipose tissue in healthy adults. N Engl J Med (2009) 360:1518-25. doi:10.1056/NEJMoa0808949

60. Zingaretti MC, Crosta F, Vitali A, Guerrieri M, Frontini A, Cannon B, et al. The presence of UCP1 demonstrates that metabolically active adipose tissue in the neck of adult humans truly represents brown adipose tissue. FASEB J (2009) 23:3113-20. doi:10.1096/fj.09-133546

61. Orava J, Nuutila P, Lidell Martin E, Oikonen V, Noponen T, Viljanen T, et al. Different metabolic responses of human brown adipose tissue to activation by cold and insulin. Cell Metab (2011) 14:272-9. doi:10.1016/j.cmet.2011.06.012

62. Cypess AM, Chen Y-C, Sze C, Wang K, English J, Chan O, et al. Cold but not sympathomimetics activates human brown adipose tissue in vivo. Proc Natl Acad Sci U S A (2012) 109:10001-5. doi:10.1073/pnas.1207911109

63. Ouellet V, Labbe SM, Blondin DP, Phoenix S, Guerin B, Haman F, et al. Brown adipose tissue oxidative metabolism contributes to energy expenditure during acute cold exposure in humans. J Clin Invest (2012) 122:545-52. doi:10.1172/JCI60433

64. Lee P, Greenfield JR, Ho KKY, Fulham MJ. A critical appraisal of the prevalence and metabolic significance of brown adipose tissue in adult humans. Am J Physiol Endocrinol Metab (2010) 299:E601-6. doi:10.1152/ ajpendo.00298.2010

65. Pfannenberg C, Werner MK, Ripkens S, Stef I, Deckert A, Schmadl M, et al. Impact of age on the relationships of brown adipose tissue with sex and adiposity in humans. Diabetes (2010) 59:1789-93. doi:10.2337/db10-0004

66. Yoneshiro T, Aita S, Matsushita M, Okamatsu-Ogura Y, Kameya T, Kawai Y, et al. Age-related decrease in cold-activated brown adipose tissue and accumulation of body fat in healthy humans. Obesity (2011) 19:1755-60. doi:10.1038/oby. 2011.125

67. Burysek L, Houstek J. $\beta$-adrenergic stimulation of interleukin- $1 \alpha$ and interleukin-6 expression in mouse brown adipocytes. FEBS Lett (1997) 411:83-6. doi:10.1016/S0014-5793(97)00671-6
68. Buyse M, Viengchareun S, Bado A, Lombes M. Insulin and glucocorticoids differentially regulate leptin transcription and secretion in brown adipocytes. FASEB $J$ (2001) 15:1357-66. doi:10.1096/fj.00-0669com

69. Villarroya J, Cereijo R, Villarroya F. An endocrine role for brown adipose tissue? Am J Physiol Endocrinol Metab (2013) 305:E567-72. doi:10.1152/ajpendo. 00250.2013

70. Bartelt A, Bruns OT, Reimer R, Hohenberg H, Ittrich H, Peldschus K, et al. Brown adipose tissue activity controls triglyceride clearance. Nat Med (2011) 17:200-5. doi: $10.1038 / \mathrm{nm} .2297$

71. Stanford KI, Middelbeek RJW, Townsend KL, An D, Nygaard EB, Hitchcox KM, et al. Brown adipose tissue regulates glucose homeostasis and insulin sensitivity. J Clin Invest (2013) 123:215-23. doi:10.1172/JCI62308

72. Bartelt A, Heeren J. The holy grail of metabolic disease: brown adipose tissue. Curr Opin Lipidol (2012) 23:190-5. doi:10.1097/MOL.0b013e328352dcef

73. Nedergaard J, Bengtsson T, Cannon B. New powers of brown fat: fighing the metabolic syndrome. Cell Metab (2011) 13:238-40. doi:10.1016/j.cmet.2011. 02.009

74. Foster DO, Frydman ML. Nonshivering thermogenesis in the rat. II. Measurements of blood flow with microspheres point to brown adipose tissue as the dominant site of the calorigenesis induced by noradrenaline. Can J Physiol Pharmacol (1978) 56:110-22. doi:10.1139/y78-015

75. Foster DO, Frydman ML. Tissue distribution of cold-induced thermogenesis in conscious warm- or cold-acclimated rats re-evaluated from changes in tissue blood flow: the dominant role of brown adipose tissue in the replacement of shivering by non-shivering thermogenesis. Can J Physiol Pharmacol (1979) 57:257-70. doi:10.1139/y79-039

76. Thurlby PL, Trayhurn P. Regional blood flow in genetically obese (ob/ob) mice: the importance of brown adipose tissue to the reduced energy expenditure on non-shivering thermogenesis. Pflügers Arch (1980) 385:193-201. doi:10.1007/BF00647457

77. Himms-Hagen J, Desautels M. A mitochondrial defect in brown adipose tissue of the obese $(\mathrm{ob} / \mathrm{ob})$ mouse: reduced binding of purine nucleotides and a failure to respond to cold by an increase in binding. Biochem Biophys Res Commun (1978) 83:628-34. doi:10.1016/0006-291X(78)91036-7

78. Xue Y, Petrovic N, Cao R, Larsson O, Lim S, Chen S, et al. Hypoxia-independent angiogenesis in adipose tissues during cold acclimation. Cell Metab (2009) 9:99-109. doi:10.1016/j.cmet.2008.11.009

79. Shimizu I, Aprahamian T, Kikuchi R, Shimizu A, Papanicolaou KN, MacLauchlan S, et al. Vascular rarefaction mediates whitening of brown fat in obesity. J Clin Invest (2014) 124:2099-112. doi:10.1172/JCI71643

80. Mercer SW, Trayhurn P. Developmental changes in fatty acid synthesis in interscapular brown adipose tissue of lean and genetically obese $(o b / o b)$ mice. Biochem J (1983) 212:393-8.

81. Mercer SW, Trayhurn P. The development of insulin resistance in brown adipose tissue may impair the acute cold-induced activation of thermogenesis in genetically obese (ob/ob) mice. Biosci Rep (1984) 4:933-40. doi:10.1007/BF01116891

82. Mercer SW, Trayhurn P. Effects of ciglitazone on insulin resistance and thermogenic responsiveness to acute cold in brown adipose tissue of genetically obese (ob/ob) mice. FEBS Lett (1986) 195:12-6. doi:10.1016/0014-5793(86)80120-X

83. Samuvel DJ, Sundararaj KP, Nareika A, Lopes-Virella MF, Huang Y. Lactate Boosts TLR4 signaling and NF- $\mathrm{B}$ pathway-mediated gene transcription in macrophages via monocarboxylate transporters and MD-2 up-regulation. J Immunol (2009) 182:2476-84. doi:10.4049/jimmunol.0802059

84. Liu C, Wu J, Zhu J, Kuei C, Yu J, Shelton J, et al. Lactate inhibits lipolysis in fat cells through activation of an orphan G-protein-coupled receptor, GPR81. J Biol Chem (2009) 284:2811-22. doi:10.1074/jbc.M806409200

85. Carrière A, Jeanson Y, Berger-Müller S, André M, Chenouard V, Arnaud E, et al. Browning of white adipose cells by intermediate metabolites: an adaptive mechanism to alleviate redox pressure. Diabetes (2014) 63:3253-65. doi:10.2337/db13-1885

86. Petrovic N, Walden TB, Shabalina IG, Timmons JA, Cannon B, Nedergaard J. Chronic peroxisome proliferator-activated receptor $\gamma(\operatorname{PPAR} \gamma)$ Activation of epididymally derived white adipocyte cultures reveals a population of thermogenically competent, UCP1-containing adipocytes molecularly distinct from classic brown adipocytes. J Biol Chem (2010) 285:7153-64. doi:10.1074/jbc. M109.053942

87. Wu J, Boström P, Sparks Lauren M, Ye L, Choi Jang H, Giang A-H, et al. Beige adipocytes are a distinct type of thermogenic fat cell in mouse and human. Cell (2012) 150:366-76. doi:10.1016/j.cell.2012.05.016 
88. Waldén TB, Hansen IR, Timmons JA, Cannon B, Nedergaard J. Recruited vs. nonrecruited molecular signatures of brown, "brite," and white adipose tissues. Am J Physiol Endocrinol Metab (2012) 302:E19-31. doi:10.1152/ajpendo. 00249.2011

89. Nedergaard J, Cannon B. The Browning of white adipose tissue: some burning issues. Cell Metab (2014) 20:396-407. doi:10.1016/j.cmet.2014.07.005

90. DiGirolamo M, Newby FD, Lovejoy J. Lactate production in adipose tissue: a regulated function with extra-adipose implications. FASEB J (1992) 6:2405-12.

Conflict of Interest Statement: The authors declare that the research was conducted in the absence of any commercial or financial relationships that could be construed as a potential conflict of interest.
Received: 07 January 2015; paper pending published: 28 January 2015; accepted: 02 February 2015; published online: 19 February 2015.

Citation: Trayhurn P and Alomar SY (2015) Oxygen deprivation and the cellular response to hypoxia in adipocytes - perspectives on white and brown adipose tissues in obesity. Front. Endocrinol. 6:19. doi: 10.3389/fendo.2015.00019

This article was submitted to Genomic Endocrinology, a section of the journal Frontiers in Endocrinology.

Copyright (C) 2015 Trayhurn and Alomar. This is an open-access article distributed under the terms of the Creative Commons Attribution License (CC BY). The use, distribution or reproduction in other forums is permitted, provided the original author(s) or licensor are credited and that the original publication in this journal is cited, in accordance with accepted academic practice. No use, distribution or reproduction is permitted which does not comply with these terms. 